\title{
Kesenian dan Teknologi di Era Disrupsi (Studi Terhadap Akun Instagram Madihin @gazali_rumi)
}

\author{
* Rahmi Hartati ** Najla Amaly \\ * Komunikasi dan Penyiaran Islam, Fakultas Dakwah dan Ilmu Komunikasi, \\ Banjarmasin, Indonesia ** Komunikasi dan Penyiaran Islam, Fakultas Dakwah dan Ilmu \\ Komunikasi, Banjarmasin, Indonesia \\ *Email; rahmi.hartati2104@gmail.com **najlaamaly@gmail.com
}

\begin{abstract}
Instagram is one of the most popular social media in the new media age community, including the people of Indonesia. Based on survey data released by the Indonesian Internet Service Providers Association (APJII) in 2016 there were 19.9 million Instagram accounts registered. Instagram not only uses the media to post pictures of daily activities, but already uses promotional facilities and to preserve the culture. Madihin is a culture originating from South Kalimantan. The @gazali_rumi account is an Instagram account that has Madihin art posts. Social media can be the latest innovation in preserving this traditional art, while social media has become a characteristic of modern society today.
\end{abstract}

KEYWORDS Madihin, Instagram, @gazali_rumi

\begin{abstract}
ABSTRAK
Instagram adalah salah satu media sosial yang paling popular di masyarakat zaman new media saat ini, termasuk masyarakat Indonesia. Berdasarkan data hasil survei yang dikeluarkan oleh Asosiasi Penyelenggara Jasa Internet Indonesia (APJII) pada tahun 2016 sudah ada 19,9 juta akun Instagram yang terdaftar. Instagram tidak hanya berfungsi sebagai media untuk memposting gambar aktivitas sehari-hari seseorang tapi sudah dimanfaatkan sebagai sarana promosi dan untuk melestarikan budaya. Budaya Madihin merupakan salah satu budaya yang berasal dari Kalimantan Selatan. Akun @gazali_rumi merupakan salah satu akun Instagram yang memiliki postingan kesenian Madihin. Media sosial dapat menjadi inovasi terbaru dalam pelestarian kesenian tradisional ini, dimana media sosial sudah menjadi ciri khas bagi masyarakat modern saat ini.
\end{abstract}

KATA KUNCI Madihin, Instagram, @gazali_rumi

\section{Pendahuluan}

Perkembangan teknologi informasi dan komunikasi sangat berpengaruh pada kehidupan sosial masyarakat. Pada perkembangan teknologi informasi dan 
komunikasi mempengaruh bidang lain seperti bidang sosial, militer, ekonomi, politik dan lain-lain. manusia terus menciptakan inovasi-inovasi baru teknologi dikarenakan tuntutan kebutuhan manusia yang cepat dan beragam. Bagi negara berkembang perlu mengikuti perkembangan teknologi secara cepat agar tidak adanya perbedaan yang jauh dan melebar.

Perkembangan teknologi yang beredar di kalangan masyarakat tentu memiliki dua sisi dampak positif maupun negatif bagi masyarakat. Dampak positif yang didapat adalah masyarakat mendapatkan informasi yang up to date dengan cepat di berbagai bidang. Sedangkan dampak negatifnya, informasi yang disajikan tidak semuanya sesuai dengan nilai dan norma budaya suatu masyarakat.

Indonesia merupakan salah satu Negara yang terpapar perkembangan teknologi dimana dampak teknologi ini sangat mempengaruhi kultur masyarakat Indonesia. Indonesia merupakan Negara bagian Asia Tenggara yang terkenal dengan multikulturalismenya. Dikaruniai keanekaragaman suku bangsa, bahasa, dan adat istiadat yang tersebar diseluruh wilayah Indonesia memiliki pesona keragaman budaya dan kesenian tradisionalnya yang luar biasa, salah satunya adalah kesenian tradisional Madihin dari Kalimantan Selatan.

Kesenian Madihin adalah seni bertutur yang lahir, tumbuh dan berkembang di kalangan masyarakat suku Banjar. Agus Yulianto (2010:257) menyebutkan "lahirnya Madihin banyak dipengaruhi oleh kesenian Islam, yaitu kasidah dan syair-syair bercerita yang dibaca oleh masyarakat Banjar". Sekitar tahun 1970-an Madihin sangat popular di radio-radio daerah Kalimantan Selatan dibawakan oleh para seniman Madihin yang disebut Pamadihinan.

Namun seiring perkembangan zaman, pamor kesenian ini kian waktu kian meredup. Terlebih di zaman globalisasi seperti sekarang ini dinama dinamika kehidupan masyarakat mengalami perkembangan yang sangat pesat ditandai dengan pesatnya perkembangan teknologi sehingga masyarakat mulai meninggalkan budaya tradisionalnya dan beralih ke budaya modern.

Dampak dari jaman globalisasi ini sendiri adalah munculnya indikasindikasi era distrupsi. Secara bahasa, distrupsi menurut KBBI adalah tercabutnya 
dari akar. Dapat diartikan bahwa era distrupsi adalah tercabutnya nilai-nilai ataupun tidak linearnya suatu hal atau tidak dalam satu bidangnya. Selain itu indikasi ini juga merubah tatanan di masyarakat dengan begitu cepatnya. Seperti halnya tergerus nilai-nilai luhur yang tertananam dalam masyarakat, termasuk seni budaya tradisional yang sudah menjadi ciri khas peradaban suatu daerah masyarakat. Adapun secara praktis, disrupsi adalah perubahan berbagai sektor akibat digitalisasi dan "Internet of Thing" (IOT) atau "Internet untuk Segala".

Pada dasarnya perubahan adalah sebuah keniscayaan. Manusia sebagai mahkluk berbudaya beserta segala aspek kehidupannya yang terus berkembang juga harus siap dalam menghadapi setiap perubahan tersebut agar tidak musnah digerus oleh zaman. Maka diperlukan adanya tindakan aktif dalam melestarikan kebudayaan tradisional masyarakat agar tetap lestari ditengah perubahan zaman yang kian pesat.

Madihin juga mengalami perkembangan akibat dari adanya sistem modernisasi di era globalisasi saat ini. hal tersebut terlihat dari bidang tempat pementasan kesenian Madihin. awalnya Madihin hanya di pentaskan di tempattempat terbuka saja, namun dengan kecanggihan teknologi komunikasi di zaman new media sekarang ini Madihin dapat dipentaskan melalui saluran yang lebih canggih dan mampu menjangkau masyarakat yang lebih luas, misalnya melalui media sosial.

Pementasan kesenian Madihin melalui media sosial dapat menjadi inovasi terbaru dalam pelestarian kesenian tradisional ini, dimana media sosial sudah menjadi ciri khas bagi masyarakat modern saat ini. Masyarakat memanfaatkannya sebagai alat bantu sehari-hari mereka untuk memperluas penyebaran informasi sosial. Salah satu media sosial yang paling popular di kalangan masyarakat adalah Instagram. Instagram menjadi sangat diminati oleh masyarakat karena dengannya setiap pengguna dapat berbagi cerita kepada pengguna lainnya melalui foto dan video yang dilengkapi dengan caption dan fitur-fitur menarik lainnya. Fitur manarik dari Instagram inilah yang dimanfaatkan oleh Pamadihinan untuk menyiarkan pertunjukan Madihin sebagai salah satu upaya melestarikan budaya dan memperkenalkan kesenian Madihin kepada masyarakat yang lebih luas. pencetus dari salah satu akun Madihin melalui 
Instagram ini ialah @gazali_rumi. @gazali_rumi menghadirkan kesenian Madihin dalam bentuk yang berbeda dari yang lainnya. Mengusung tema kultural, komedi, dan kekinian, kesenian Madihin yang ditampilkannya menjadi lebih menarik dengan sentuhan modernisasi.

Berdasarkan latar belakang yang sudah di paparkan diatas, penulis tertarik untuk melakukan penelitian terhadap akun Instagram @gazali_rumi dalam rangka pengembangan teori, strategi serta metodologi pelestarian kesenian tradisional itu sendiri. Fokus penelitian ini bertujuan untuk menggambarkan bagaimana pementasan kesenian Madihin melalui Instagram sebagai media pelestarian kesenian tradisional di era disrupsi pada akun @gazali_rumi. Hasil dari penelitian ini di harapkan dapat menambah khazanah penelitian terhadap kesenian tradisional Madihin dari Kalimantan Selatan dan sebagai sarana pelestarian budaya serta kesenian tradisional Indonesia. 


\section{Kajian Teori}

Munculnya internet yang merupakan teknologi informasi saat ini menciptakan cyberspace di masyarakat. Kehidupan yang diciptakan internet yang luas dimana manusia akan dihadapi oleh realita baru yaitu realita virtual yang beragam dari seluruh dunia. Teknologi komputer telah mendampingi internet dan menjadi sebuah teknologi informasi yang luar biasa, dalam hal ini dapat disebut juga sebagai CMC. Teknologi informasi komunikasi ini tidak lagi menjadi media komunikasi satu arah namun telah menjadi media 2 arah. Sehingga adanya perbedaan dari teknologi informasi tradisional (era mekanik reproduksi massa) dengan modern (era cybernation). Atau hal ini disebut sebagai the first media age dan the second media age.

Tabel 1 Perbedaan dari media tradisional dengan media modern dari

\section{McLuhan}

\begin{tabular}{|l|l|}
\hline \multicolumn{1}{|c|}{ The First Media Age } & \multicolumn{1}{c|}{ The Second Media Age } \\
\hline Produksi yang tersentralisasi & Desentralisasi \\
\hline Komunikasi 1 Arah & Komunikasi 2 Arah \\
\hline Media dikendalikan & Tidak dikendalikan \\
\hline Pengaruh bersifat umum & Pengaruh bersifat individual \\
\hline Membentuk Kesadaran Sosial & Beroreintasi Secara Individual \\
\hline Siaran (broadcast) & Jejaring (networks) \\
\hline
\end{tabular}

Perkembangan teknologi informasi dan komunikasi telah pula menyebabkan hubungan dunia menjadi tanpa batas, dan menyebabkan perubahan sosial, ekonomi, dan budaya secara signifikan berlangsung dengan demikian cepat. Kehidupan manusia modern saat ini tidak dapat dilepaskan dari bahkan terkadang sangat bergantung pada kemajuan teknologi canggih, salah satunya adalah internet. Di satu sisi kemajuan teknologi internet membawa dampak positif, seperti adanya media komunikasi yang cepat sepert e-mail, sosial media. Mempermudah urusan pribadi dengan instansi-instansi seperti internet Banking, Cyber Bank, On-line Business dan sebagainya. Namun juga membawa dampak negatif, dengan munculnya berbagai jenis kejahata internet (cyber crime) cyber crime merupakan bagian sisi paling buruk dari Masyarakat informasi. 
Perubahan manusia terlihat dari empat era yaitu era tribal, era scribal, era mekanik, dan era elektrik. Dimana manusia berangkat dari era lisan kemudian beralih ke era tulisan dan dilanjutkan ke era indusstri dimana telah ditemukan alat cetak yang mulai mencetak tulisan untuk diperbanyak dan disebarkan dan pada era saat ini yaitu era teknologi informasi dimana ditemukan berbagai media teknologi informasi sepeerti media massa. Dalam kehidupan nyata ini, pengaruh dari pada cyber society ada yang bersifat positif maupun yang bersifat negatif. Pengaruh Positif Cyber Society, diantaranya :

a. Mempermudah berkomunikasi

b. Memudahkan dalam memperoleh informasi yang diinginkan

c. Mempermudah dalam bertransaksi dengan orang lain yang dapat dimanfaatkan sebagai ranah bisnis, politik dan lain-lain.

Sedangkan pengaruh negatif Cyber Society adalah banyaknya kasus-kasus kejahatan yang terjadi melalui dunia siber (cyber crime) seperti pornografi, penipuan bahkan penculikan. Peristiwa ini bersangkutan dengan pemakaian komputer dalam masyarakat. Komputer yang terus berkembang menjadi salah satu teknologi informasi dan komunikasi Computer Mediated Communication (CMC). Pemakai CMC ini telah membentuk cyber society. Dimana para individu manusia yang terbatas akan wilayah, makan dalam cybersociety individu akan terhubung tanpa ada batas waktu dan tempat tanpa perlu bertemu. Karena hal inilah CMC selain memiliki dampak positif, adanya cyber crime yang merupakan dampak negatif dari CMC. CMC juga telah membuat sebuah budaya baru dimana adanya budaya yang membuat seseorang tidak melakukan kontak langsung terhadap lingkungan sosial (isolasi sosial), karena telah terkurung dalam dunia maya atau semu.

\section{Metode Penelitian}

Penelitian ini adalah kajian studi kasus dengan pendekatan deksriptif kualitatif, yakni penelitian yang dimaksud untuk mengumpulkan informasi mengenai suatu gejala yang ada, menurut fenomena yang terjadi apa adanya pada saat penelitian dilakukan, sehingga dapat menyingkap fakta dengan menganalisis data kemudian disajikan secara sistematis agar lebih mudah dipahami. tujuan penelitian deskriptif ini adalah untuk memberikan gambaran 
bagaimana pementasan kesenian Madihin melalui Instagram sebagai media pelestarian kesenian tradisional di era disrupsi pada akun @gazali_rumi.

Subjek pada penelitian ini adalah akun Instagram @gazali_rumi dan objek penelitiannya adalah video kesenian Madihin yang diunggah oleh akun @gazali_rumi ke Instagram dengan fokus penelitian bagaimana penggunaan Instagram sebagai media pelestarian kesenian Madihin di Kalimantan Selatan.

Teknik pengumpulan data yang digunakan berupa Observasi yaitu dengan pengamatan dan pencatatan yang sitematis terhadap gejala-gejala yang diteliti. Penggunaan metode observasi dalam penelitian ini memungkinkan data dikumpulkan secara efektif bila dilakukan secara langsung mengamati objek yang diteliti. Teknik ini penulis gunakan untuk mengamati langsung video yang di unggah ke akun Instagram @gazali_rumi untuk melihat bagaimana penggunaan Instagram sebagai media pelestarian kesenian Madihin di Kalimantan Selatan. Selain itu, dalam mencari atau menentukan sumber data penulis juga melakukan wawancara terhadap pemilik akun Instagram @gazali_rumi. Teknik pengumpulan data yang digunakan selanjutnya dalam penelitian ini menggunakan teknik dokumentasi, yakni pengumpulan data dengan penyelidikan benda-benda, buku, majalah, surat kabar, dan sebagainya. Berdasarkan hal tersebut, dengan teknik dokumentasi penulis melakukan pencarian dan pengambilan informasi yang sifatnya berupa gambar maupun teks yang menjelaskan dan menguraikan mengenai hubungan dengan arah penelitian. Data yang ingin diperoleh dari metode ini adalah data mengenai akun Instagram @gazali_rumi, berupa gambar, video dan fitur-fitur yang ada lainnya. Teknik Analisis Data yang digunakan dalam penelitian ini adalah analisis deskriptif kualitatif.

\section{Hasil Penelitian dan Pembahasan \\ Gambaran Umum Akun Instagram @gazali_rumi}

@gazali_rumi adalah sebuah akun Instagram pribadi milik seorang Pamadihinan muda asal Sungai Tuan Ulu Kabupaten Banjar, Kalimantan Selatan yang bernama Gazali Rahman. Nama @gazali_rumi diambil dari nama pemilik akun sendiri dan nama sebuah sanggar UKM di kampus tempat pemilik akun 
berkuliah dan mendalami kesenian Madihin yakni sanggar Ar-Rumi Institut Agama Islam Darussalam Martapura.

@gazali_rumi merupakan akun Instagram pertama yang mengunggah video pementasan kesenian Madihin ke media sosial Instagram. Isi Madihinnya mengandung berbagai unsur, selain mengkritisi keadaan sosial yang sedang hangat di tengah-tengah masyarakat, ia juga memasukkan pesan nasihat kebaikan dalam syair-syair Madihinnya yang dikemas dengan lelucon sehingga terlihat lebih menarik dan berbeda dari yang lainnya.

Penggunaan Instagram untuk mengunggah video pertunjukan Madihin diakui pemilik akun dilatar belakangi oleh ketertarikannya dengan fitur vidgram yang bisa membuat video berdurasi satu menit. Tahun 2015-2016 adalah awal mula populernya masyarakat Kalimantan Selatan khususnya warga Banjar berpindah dari menggunakan media sosial Facebook ke Instagram. Kesempatan tersebut dimanfaatkannya untuk membuat vidgram versi kesenian Madihin.

\section{Kesenian Madihin}

Kesenian Madihin dikenal sebagai kesenian khas Urang Banjar yang berasal dari Kalimantan Selatan karena tidak terdapat di daerah lain. (Jahdiah, 2010). Kesenian Madihin diperkirakan sudah ada sejak setelah Islam masuk dan berkembang di Kalimantan, yakni pada tahun 1800an. (Agus Yulianto, 2010:257). Lahirnya Madihin banyak dipengaruhi oleh kesenian Islam, yaitu kasidah dan syair -syair bercerita yang dibaca oleh masyarakat Banjar. Wardani (1999:13) pada awal pertumbuhannya, menurut Sanderta dan Rasyid, kesenian Madihin merupakan bentuk hiburan bagi kalangan Keraton Banjar. Namun dalam perkembangan selanjutnya, Madihin ini tidak hanya dikenal di lingkungan istana, tetapi juga ke masyarakat luas. Oleh sebab itu, fungsi Madihin pun berkembang dari sekedar alat penghibur saja menjadi media penyampai nasehat dan kritik sosial maupun penyampaian pesan-pesan yang mengandung misi khusus seperti misi pendidikan dan keagamaan.

Menurut beberapa sumber Pamadihinan, kesenian Madihin diduga mulai berkembang dari Desa Tawia, Kecamatan Angkinang, Kabupaten Hulu Sungai Selatan, Kalimantan Selatan. Salah seorang Pamadihinan yang berasal dari desa tersebut yang dikenal dengan nama Dullah Nyangnyang mempunyai 
peranan yang cukup besar dalam melestarikan dan mengembangkan kesenian Madihin ini. (Wardani, 1999:14). Banyak Pamadihinan muda yang belajar kepadanya. Namun pendapat lain yang juga bisa dibenarkan ialah pendapat yang menyatakan bahwa kesenian Madihin berasal dari Kecamatan Paringin, Kabupaten Hulu Sungai Utara, Kalimantan Selatan, karena dahulu Dullah Nyangnyang sempat lama bermukim di daerah tersebut dan mengembangkan kesenian Madihin disana. (Durratul, 2017).

Seni Madihin ini sangat cepat menyebar dari satu daerah ke daerah lainnya. Cepatnya proses penyebaran kesenian ini tidak lepas dari faktor mudahnya kesenian ini beradaptasi dengan lingkungan barunya, baik yang menyangkut pemakaian bahasa maupun substansi isinya yang selalu komunikatif, lucu, dan menyentuh masyarakat pendengarnya.

Madihin termasuk dalam genre puisi menurut kaidah konvensional sastra lisan Banjar. Sebagaimana menurut Seman, nama Madihin berasal dari kata madah, yakni sejenis puisi lama dalam sastra Indonesia. (Seman, 2008:5). Pendapat ini beralasan karena kesenian Madihin menyajikan syair-syair sebagai suatu puisi. Secara fisik Madihin tidak berbeda dari syair, yaitu dalam tiap bait terdiri atas empat baris. Tapi berbeda dengan syair, Madihin tidak bersifat naratif, tidak berkisah atau tidak memiliki alur cerita sebagaimana syair. (Kawi, 1994). Pendapat lain mengatakan kata "Madihin" berasal dari kata "madah" artinya berkata-kata. Madah bisa juga diartikan sebagai kata-kata pujian jika diambil dari bahasa Arab, karena syair-syair dalam pementasan Madihin juga sering berupa pujian-pujian. Thaha (2000:23) adapula yang berpendapat bahwa kata Madihin berasal dari bahasa Banjar yaitu papadahan atau mamadahi yang berarti memberi nasihat. Hal ini juga dapat dibenarkan karena syair-syair yang dibacakan oleh Pamadihinan dalam kesenian Madihin sarat akan nasihat kebaikan bagi penonton dan pendengarnya.

Pertunjukan kesenian Madihin hanya diiringi oleh satu insrtumen atau alat musik saja yang disebut dengan Tarbang (alat tabuh seperti rebana). Alat musik tarbang ini terbuat dari kulit kambing yang dibingkai dengan kayu dan pengikat dari rotan. (Yulianto, 2010:260). Seorang Pamadihinan sendiri harus memiliki keterampilan khusus dalam memukul Tarbang agar bunyi yang dikeluarkannya 
sesuai dengan penyajian syair-syair yang dibacakan. Irama Terbang yang dipukul oleh Pamadihinan mempunyai notasi yang sama dan datar atau monoton, kecuali pada saat-saat prolog dan epilog, yang iramanya terjadi perubahan nada yang menunjukkan tanda awal dan akhir kesenian Madihin itu disajikan. Pementasan Madihin bisa dibawakan oleh 1 (satu) sampai 4 (empat) orang Pamadihinan pria dan/wanita. Para Pamadihinan biasanya memakai kostum bebas saja, namun tidak jarang pula mereka memakai kostum khas Banjar sehingga penampilan lebih menarik. Tempat digelarnya pementasan Madihin pada awalnya hanya ditempat-tempat terbuka, seperti pekarangan yang luas, tanah lapang, atau di lahan sawah yang padinya sudah dipanen. (Jahdiah, 2010). Bahkan dahulu, sekitar tahun 1970-an Madihin sempat populer di radio-radio daerah Kaimantan Selatan yang dibawakan Pamadihinan (seniman Madihin). Saat itu masyarakat sangat menggemarinya, tidak hanya mendengar melalui radio, mereka bahkan membeli kasetnya. Saat ini Madihin tidak hanya di perdengarkan melalui pertunjukan langsung, kaset, radio ataupun televisi, tapi terus di kembangkan hingga bisa ditonton melalui media sosial Instagram.

\section{Media Sosial Instagram}

Nama Instagram sendiri terdiri dari dua kata, yakni "insta" berasal dari kata "instant" maksudnya "foto instan" yang ditampilkannya, dalam perkembangannya Instagram juga menampilkan foto bergerak atau video, dan kata "gram" berasal dari kata "telegram" yang cara kerjanya untuk mengirimkan informasi kepada orang lain dengan cepat menggunakan jaringan internet. (Pakhri, 2017:34). Secara sederhana, Instagram dapat diartikan sebagai suatu media untuk berbagi cerita, peristiwa dan pengalaman melalui foto dan video yang bisa ditambahkan caption sesuai dengan keinginan si pemilik akun, yang mana bisa disebarkan dan dapat dilihat kapan saja, dimana saja, dan oleh siapapun di seluruh belahan dunia ini selagi masih tersambung dengan saluran internet.

Instagram diciptakan oleh Kevin Systrom dan Mike Krieger yang diluncurkan pada oktober 2010. Awal diluncurkan aplikasi ini, Kevin dan Mike berfokus pada fitur foto, dikarenakan bagi mereka sulit untuk mengurangi fiturfitur yang ada pada waktu itu. Beberapa bulan setelah diluncurkan, Instagram 
mampu meraih 1 juta pengguna pada desember 2010. Bahkan berdasarkan data hasil survei yang dikeluarkan oleh Asosiasi Penyelenggara Jasa Internet Indonesia (APJII) pada tahun 2016 tercatat sudah ada 19,9 juta akun Instagram yang terdaftar atau sekitar 15\% dari jumlah keseluruhan pengguna internet dan media sosial di Indonesia. Bahkan di langsir dari Detik.com pertanggal 22 Juni 2016, Instagram manyatakan bahwa penggunanya kini telah mecapai 500 juta pengguna aktif bulanan dan 300 juta pengguna aktif harian. Setiap harinya, ada 4,2 miliar tanda like dan lebih dari 95 juta foto atau video dibagikan ke sesama pengguna. Dan jumlah tersebut terus bertambah hingga sekarang. Dengan mengantongi data tersebut maka Instagram dapat dijadikan sebagai medium yang sangat menjanjikan dalam menarik banyak peminat untuk melestarikan budaya dan kesenian Madihin.

Keunikan Instagram ada pada bingkai foto maupun video berbentuk persegi. Instagram juga memiliki fitur edit foto maupun video yang menjadi penarik minat pengguna untuk menunggah foto maupun video ke Instagram. Keunikan Instagram yang lain ada pada durasi video yang tidak lebih dari 60 detik, sehingga menjadi sebuah tantangan bagi pengguna agar bisa mengemas pesannya dengan lebih baik karena batas waktu yang disedikan oleh Instagram melalui fitur yang sering disebut sebagai vidgram ini.

Fitur vidgram saat ini sangat banyak dipakai oleh pengguna Instagram khususnya para komunitas yang menamakan diri mereka sebagai komunitas vidgram. Biasanya mereka mengunggah video-video dagelan, komedi, cinta, dan apa yang sedang hangat diperbincangkan. Penonton video mereka sangatlah banyak, bisa mencapai satu juta tayangan. Ini menjadi motivasi bagi para penggiat kesenian madihin untuk menghadirkan video yang memiliki pesanpesan moral maupun nilai-nilai kebaikan dan kearifan lokal mellaui kesenian madihin di antara banyaknya video-video yang memuat konten lainnya.

\section{Pementasan Kesenian Madihin Pada Akun Instagram @gazali_rumi Sebagai Media Pelestarian Budaya dan Kesenian Daerah}

Pementasan kesenian Madihin melalui Instagram merupakan sebuah inovasi terbaru dalam upaya pelestarian budaya dan kesenian khas daerah Kalimantan Selatan. @gazali_rumi menggunakan fitur vidgram sebagai medianya 
dalam menyiarkan pementasan kesenian Madihin. Pemilik akun @gazali_rumi dibantu oleh rekan-rekannya yang tergabung dalam satu grup sanggar seni Madihin Ar-Rumi dari Martapura kabupaten Banjar memproduksi sendiri video Madihinnya. Hasil dari produksi video itulah yang akhirnya disebar ke beberapa media sosial yang dimiliki seperti Instagram dan youtube sebagai pemenuh kebutuhan khalayak akan hiburan, informasi dan tontonan yang mengedukasi. Pada video tersebut terdapat text box yang bertuliskan sayir-syair Madihin yang mereka bacakan atau yang lebih dikenal dengan dengan sebutan subtitle. subtitle ini memudahkan penonton video Madihin @gazali_rumi dalam melihat, mendengarkan dan memahami isi kandungan syair Madihin yang disampaikannya agar tidak terjadi distorsi komunikasi ketika hanya mengandalkan indera pendengaran saja. Tidak hanya subtitle yang ditambahkan admin dalam video Madihinnya, mereka juga menambahkan sedikit teknik editing dengan sentuhan komedi sebagaimana identiknya kesenian Madihin yang jenaka agar lebih menarik perhatian penonton dari pengguna Instagram. Penambahan teknik editing dalam pembuatan video Madihin ini ternyata berhasil menarik perhatian netizen (warga net) lebih banyak, di samping karena kesenian Madihin yang mereka dibawakan memang bagus dan syair-syairnya mampu menyentuh hati para penontonnya.

Pada beberapa video yang lain, @gazali_rumi menampilkan Madihin dalam kemasan sedikit berbeda, dengan kostum biasa saja tanpa pernak pernik khas Banjar dan pada bagian sampul video diberikan judul yang jenaka namun pada bagian lirik diselipkan berbagai pesan positif bagi para penontonnya. Pesan-pesan tersebut juga di bungkus apik dalam syair yang menggelitik dengan tema mengkritisi kejadian sosial yang tengah hangat diperbincangkan oleh netizen di zaman sekarang namun tetap pada konteks tujuan menyampaikan pesan kebaikan tersebut. Kritis namun jenaka menjadi ciri khas kesenian madihin @gazali_rumi sehingga bukan semata sebagai media hiburan bagi masyarakat namun juga sekaligus sebagai media komunikasi yang efektif dalam kritik sosial serta penyampaian pesan kebaikan kepada masyarakat melalui syair-syair madihin yang mereka bawakan pada akun @gazali_rumi. 
Berikut adalah kutipan syair Madihin oleh Pamadihinan sanggar Ar-Rumi yang di unggah ke akun Instgaram @gazali_rumi pada tanggal 11 Mei 2017 lalu yang berjudul "Nishfu Sya'ban":

Malam Nishfu Sya'ban ba'amalan bagus

(malam Nishfu Sya'ban beribadah bagus)

Sumbahyang tasbih, jua mudahan dosa kita berataan dihapus

(sholat tasbih, dan mudahan dosa kita semua dihapus)

Jua coming soon ini menulis status

(dan coming soon ini menulis status)

Sudah tuntung ba'amalan 2375 lalu di upload ke medsos

(sudah selesai beramalan (membaca tasbih) sebanyak 2375 kemudian di upload ke medsos)

\section{Damintu contoh generasi ihnil manfus}

(seperti itu contoh generasi "ihnil manfus")

NB: (selamat memperingati Malam Nishfu Sya'ban dan ba'amalan lah tulus kepada Allah SWT, dan jangan riya, iya kalo)

(selamat mempertingati malam Nishfu Sya'ban dan beribadahlah tulus kepada Allah SWT, dan jangan riya, iya kan)

Sumber: Instagram @gazali_rumi

Madihin yang disampaikan melalui akun @gazali_rumi sedikit berbeda dari pakem Madihin pada umumnya, yakni tanpa ada salam pembuka maupun penutup. Ini dikarenakan fitur vidgram yang hanya memiliki durasi 1 menit. Oleh karena itu penyampaian Madihin langsung kepada isinya saja agar maksud yang diinginkan secara efektif tersampaikan.

Jika dicermati, dari syair Madihin di atas dapat dipetik pesan yang ingin disampaikan oleh pamadihinan pada akun @gazali_rumi diantaranya ketika datang Malam Nisyfu Sya'ban yang termasuk malam-malam penting bagi umat Islam, maka banyak-banyaklah beribadah mendekatkan diri kepada Allah SWT. sebagai bentuk ketakwaan kepada-Nya, namun esensi ketakwaan tersebut jangan sampai dirusak dengan perbuatan riya (menunjuk-nunjukkan) kepada umat manusia. 
Dari pesan tersebut dapat dicermati bahwa lirik madihin di atas merupakan kritik pamadihinan terhadap gejala sosial yang ada disekitarnya ketika datang momen Malam Nishfu Sya'ban, yakni maraknya orang-orang yang mengumbar kegiatan ibadahnya ke media sosial sebagai bentuk eksistensi diri telah melakukan suatu kebaikan yang mana hal tersebut jika dilakukan dengan kesombongan maka termasuk perbuatan riya di dalam agama Islam. Meski tanpa kesombongan, perbuatan tersebut juga akan memicu reaksi yang berbeda-beda dari masyarakat yang melihatnya. Maka dari itu dalam madihin tersebut @gazali_rumi berpesan kepada warga net agar lebih bijak lagi dalam merayakan malam yang sacral tersebut dan hindari perbuatan yang dapat memicu pertentangan di masyarakat seperti halnya perbuatan riya dalam beribadah.

Dalam video lain @gazali_rumi menampilkan madihin dengan konsep yang berbeda, di alam terbuka dan tanpa alat musik tarbang namun tetap dengan nada syair khas madihin. video madihin tersebut berjudul Madihin Matang Keladan yang diunggah pada tanggal 19 Oktober 2019 lalu. Madihin tersebut berisikan lirik sebagai berikut:

Kami sedang berada di puncak Matang Keladan

Kita jaga alamnya, jangan buang sampah disini sembarangan

Ini si Gazali, sungguh aneh kelakuan

Karena semalam saya pernah ajak dia ke Matang Keladan

Saya ajak naik kelotok (perahu khas Kalimantan) dia mabuk perjalanan

Saya ajak hiking, karena badannya gendut setengah mati ngos-ngosan

Saya ajak memancing, dia makan umpan ikan

Saya ajak dia foto selfie, pas mukanya keliatan merusak pemandangan

Saya ajak camping, dia malah kesurupan

Setelah di obati dia punya kesalahan

Dia berwisata buang sampah sembarangan

(berwisata dan jaga alamnya)

Sumber: Instagram @gazali_rumi 
Syair madihin di atas memiliki perbedaan jika dibandingkan dengan kebanyakan syair video madihin yang biasa dibuat dan diunggah oleh @gazali_rumi. Perbedaan tersebut terletak pada bahasa yang digunakannya. Biasanya @gazali_rumi mengunggah video madihin menggunakan bahasa daerah Suku Banjar sebagai bahasa asal daerah kesenian ini, namun pada video kali ini yang digunakan ialah bahasa Indonesia. Hal tersebut dilakukan agar penonton yang tidak mengerti bahasa banjar bisa menikmati dan memahami secara langsung pesan yang ingin disampaikan oleh pemadihinan.

Video tersebut berlatar Bukit Matang Keladan yang ada di Aranio Kabupaten Banjar. Video ini dibuat sebagai kritik terhadap para wisatawan yang sering membuang sampah sembarangan di tempat wisata khususnya wisata alamnya. Karena itu melalui video madihin ini berpesan kepada para penonton agar senantiasa menjaga kebersihan alam dan lingkungan ditempat wisata. Jangan sembarangan membuang sampah karena dapat merusak kebersihan dan keindahan lingkungan alam tempat wisata tersebut. kerusakan yang ada di muka bumi disebabkan oleh perbuatan tangan manusia sendiri, maka sudah seharusnya manusia sadar untuk menjaga dan merawat alamnya agar tidak membawa dampak buruk bagi kehidupan manusia.

Selain video Madihin, admin @gazali_rumi juga mengunggah foto maupun video kegiatan positif yang dilakukannya di berbagai daerah dengan tujuan memberikan insprirasi dan motivasi kepada pengguna Instagram lainnya dan masyarakat luas agar hal positif tersebut dapat diketahui dan diikuti. 


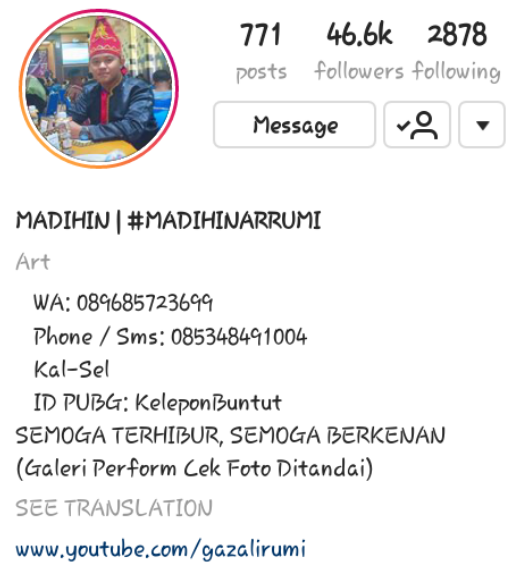

Gambar 1. Screenshoot bio akun Gambar 2. Screenshoot video Instagram @gazali_rumi

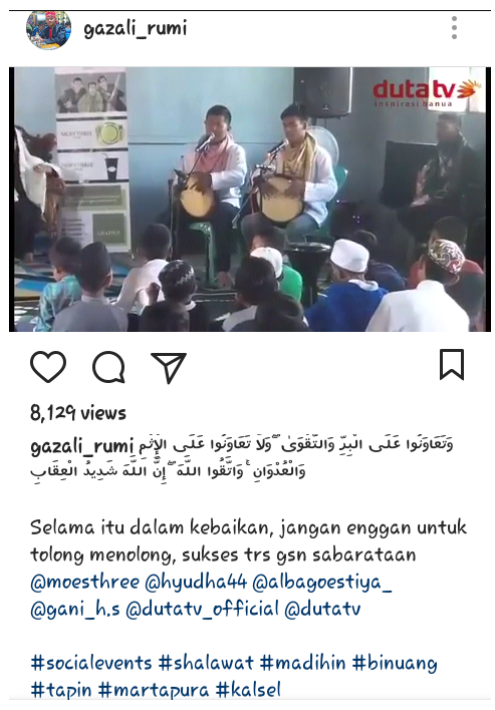

kegiatan Madihin

Sanggar Ar-Rumi pada akun @gazali_rumi

\section{Tanggapan Masyarakat (Netizen)}

Tanggapan atau respond dapat diartikan sebagai suatu sikap atas jawaban terhadap suatu peristiwa atau perilaku yang sedang atau telah terjadi. Seperti yang sudah di paparkan di atas, dalam hal ini masyarakat memberikan komentar yang beragam dan positif. Hal ini terbukti dari banyaknya pengikut (follower), penonton (viewer), dan yang menyukai (liker) video Madihin yang diunggah ke akun @gazali_rumi. Data terakhir yang penulis konfirmasi hingga penelitian ini selesai dilakukan, pengikut akun Instagram @gazali_rumi sudah berjumlah sekitar 63.400an orang lebih, pengguna Instagram yang menonton setiap video kirimannya bisa mencapai lebih dari 26.700an orang, dan jumlah yang menyukai video kirimannya bisa mencapai 8.000 an orang lebih pada setiap postingan atau unggahannya. Hal ini menandakan bahwa penggunaan fitur vidgram yang dilakukan oleh akun @gazali_rumi untuk menyiarkan video Madihinnnya sangat menarik bagi netizen maupun masyarakat luas sehingga memancing orang untuk menjadikan @gazali_rumi sebagai tontonan hiburan dan/atau sumber informasi. Bahkan beberapa pengguna akun Instagram yang 
menonton maupun menjadi pengikut @gazali_rumi memberikan komentarnya terhadap video Madihin @gazali_rumi. Diantaranya mengatakan: mantap; keren; masyaAllah membuat merinding, dll.

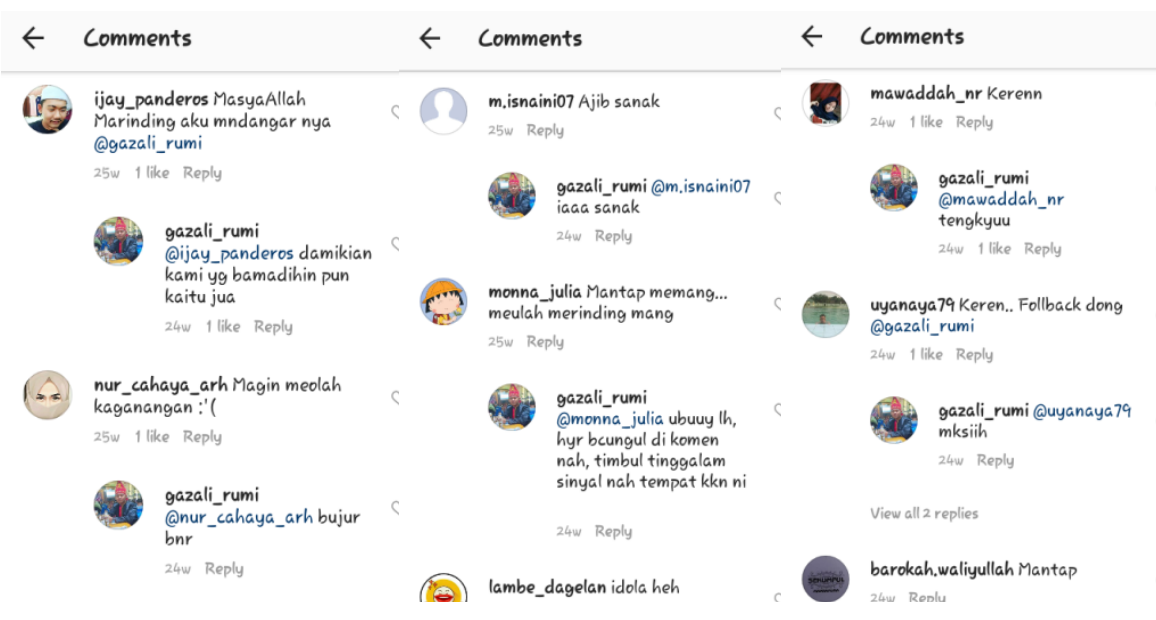

Gambar 3. Gambar kolom komentar pada akun Instagram @gazali_rumi

Berdasarkan uraian tersebut, penulis dapat menggambarkan bahwa penggunaan kesenian Madihin melalui Instagram sebagai media pelestarian budaya dan kesenian tradisional madihin oleh akun @gazali_rumi adalah suatu inovasi yang menarik untuk terus dikembangkan agar kesenian tradisional khas Banjar di Kalimantan Selatan juga bisa terus berkembang semakin maju sesuai dengan perkembangan zaman, teknologi dan masyarakatanya. Perpaduan antara kesenian tradisional dengan teknologi komunikasi yang maju seperti media sosial Instagram menjadi suatu media komunikasi yang sangat menarik bagi masyarakat karena: (1) Sesuai dengan perkembangan zaman namun tanpa meninggalkan tradisi yang sudah membudaya dan berkembang di masyarakat. (2) Bersifat sangat efektif dan efisien karena lebih cepat, mudah dan murah, serta jangkauan pemirsa lebih luas. oleh karena itu sudah seharusnya diketahui oleh khalayak dan dimanfaatkan dengan sebaik-baiknya oleh para penggiat kesenian daerah untuk lebih mengembangkan metode ini menggunakan berbagai media teknologi, informasi dan komunikasi yang ada sesuai perkembangan zaman agar kesenian tradisional tidak pudar ditelan zaman sehingga kesenian tersebut tetap 
lestari dan dikenal oleh masyarakat luas khususnya generasi penerus di masa mendatang sebagai identitas khas daerah Banjar.

\section{Simpulan}

Berdasarkan berbagai penjelasan di atas, dapat diambil kesimpulan bahwa kesenian Madihin adalah kesenian tradisional khas Banjar dari Kalimantan Selatan. Kesenian ini dapat dijadikan sebagai media komunikasi yang efektif dalam hala hiburan, pendidikan, keagamaan maupun kritik sosial karena dalam syair-syairnya mengandung nasihat-nasihat kebaikan yang berlandaskan pada nilai dan norma yang berlaku di masyarakat serta dari kitab suci Al-Qur'an dan Sunnah. Seiring perkembangan zaman yang kian modern, diperlukan adanya inovasi dalam upaya pelestarian kesenian Madihin sebagai budaya dan kesenian khas daerah serta media komunikasi tradisional masyarakat, salah satunya melalui media sosial Instagram. @gazali_rumi adalah salah satu akun pencetus penyiaran kesenian Madihin melalui Instagram mendapat respon yang positif dari masyarakat, terbukti dari banyaknya pengikut akun tersebut yang berjumlah 63.400an orang, penontonnya lebih dari 26.700an orang dan yang menyukai setiap kirimannya mencapai 8.000 an orang lebih pada setiap postingan atau unggahannya. Dengan demikian maka media sosial instagram dapat menjadi media yang efektif dalam upaya pengenalan dan pelstarian kesenian Madihin kepada masyarakat Millenial di Era Disrupsi saat ini.

Akan sangat bagus jika banyak penggiat kesenian tradisional lainnya yang memanfaatkan media ini sebagai media pelestarian budaya dan kesenian tradisional agar tidak terkesan membosankan dan ketinggalan zaman serta mampu menjangkau penikmat yang lebih banyak dan lebih luas serta mampu menyentuh berbagai lapisan masyarakat. Selain itu diharapkan adanya lembaga khusus yang bergerak dibidang seni di bawah naungan pemerintah dan dalam bimbingan budayawan agar pelestarian budaya dan kesenian tradisional melalui media teknologi canggih ini lebih terarah dan terorganisir.

\section{Referensi}


A. H. Wardani. 1999. Nilai budaya dalam sastra traditional Madihin. Banjarmasin: FKIP Universitas Lambung Mangkurat.

Agus Yulianto. 2010. Madihin: Tradisi Tutur dariZaman de Zaman. Banjarbaru: Balai Bahasa Banjarmasin.

Departemen Agama Republik Indonesia. 1976. Terjemah Dan Tafsir Alquran. Bandung: Firma Sumatra.

Djantera Kawi, dkk. 1994. Analisis Struktur Sastra Lisan Madihin. Banjarmasin: Depdikbud.

Durratul Hijaziah. 2017. Komunikasi Dakwah Seni Tradisional Madihin Anang Syahrani. Dalam The $2^{\text {nd }}$ BUAF Committee (ed.). Proceeding Contemporary Islam In The Eyes of Young Researchers (hlm.539-554). Banjarmasin: UIN Antasari Banjarmasin

Jahdiah. 2010. Lamut dan Madihin:Kesenian Tradisional Banjar di Tengah Arus Modernisasi, Banjarbaru: Balai Bahasa Banjarmasin.

Kitab al-Bukhari (no. 2278) dan Muslim (no. 1829).

Pakhri, A. M. 2017. Penggunaan Fitur Vidgram Sebagai Trend Media Dakwah (Studi Deskriptif Kualitatif pada Akun @Yufid.Tv di Instagram). Skripsi tidak diterbitkan. Makassar: UIN Alauddin Makassar.

Penelitian Kementerian Komunikasi dan Teknologi tahun 2016 tentang Penggunaan Internet.

Syamsiar Seman. 2008. Kesenian Tradisonal Banjar Lamut Madihin, Pantun. Banjarmasin: Lembaga Pengkajian dan Pelestarian Budaya Banjar Kalimantan Selatan.

Tafsir Ibnu Katsir dan "Taissirul kariimir Rahmaan"

Thaha. 2000. pantun, Madihin, lamut.

West, Richard \& Lynn H. Tuner. 2013. Pengantar teori komunikasi: analisis dan aplikasi. Penerjemah: maria natalia. Penerbit Salemba Humanika : Jakarta Internet:

http://www.lemhannas.go.id/portal/images/stories/humas/jurnal/edisi16/jurnal \%20edisi\%2016 materi\%205.pdf

http://digilib.uinsuka.ac.id/8371/1/MOHAMMAD\%20ZAMRONI\%20PERKEMBAN GAN\%20TEKNOLOGI\%20KOMUNIKASI\%20DAN\%20DAMPAKNYA\%20TE RHADAP\%20KEHIDUPAN.pdf 